Advances in Geosciences, 6, 57-61, 2006

SRef-ID: $1680-7359 /$ adgeo/2006-6-57

European Geosciences Union

(c) 2006 Author(s). This work is licensed

under a Creative Commons License.

\title{
ENSO and sandy beach macrobenthos of the tropical East Pacific: some speculations
}

\author{
T. Vanagt, E. Beekman, M. Vincx, and S. Degraer \\ Gent University, Department of Biology, Marine Biology Section, B-9000 Gent, Belgium
}

Received: 4 July 2005 - Revised: 16 November 2005 - Accepted: 21 November 2005 - Published: 9 January 2006

\begin{abstract}
The influence of the ENSO cycle on marine fauna and flora has only recently been given the attention it deserves. The very strong 1997-1998 El Niño and its obvious effects on marine biota was a key point in ENSO research, but unfortunately few quantitative data about the 1997-1998 El Niño itself are available.

To gather information about the effect of ENSO on the macrobenthos, we performed a bi-weekly transect monitoring on an Ecuadorian sandy beach in 2000-2001, during the strong La Niña following the 1997-1998 El Niño, and in the normal period of 2002-2004.

In this paper, intertidal macrofaunal densities at higher taxonomic level are used to compare a La Niña phase with the 'normal' situation. The few existing documents about El Niño and sandy beach macrobenthos, and scattered data from previous and current research, were used to complete the picture.

Total macrobenthos densities were 300\% lower during the La Niña phase compared with equal months in the normal phase. Especially Crustacea and Mollusca showed a marked increase in densities towards the normal situation (94\% and $341 \%$ respectively). Polychaeta and Echinodermata, however, showed higher densities during the La Niña phase (22\% and $73 \%$ respectively).

Two possible explanations are proposed. (1) Low densities during the La Niña could be due to the very strong preceding El Niño, suggesting the populations were still recovering. This hypothesis is supported by previous work done in the south of Peru. This is, however, a cold water system, compared to the Ecuadorian warm water system. (2) The second hypothesis states that a La Niña will have a very severe impact on the intertidal macrofauna of a warm water system like the Ecuadorian coast.
\end{abstract}

Correspondence to: $\mathrm{T}$. Vanagt

(thomas.vanagt@ugent.be)

\section{Introduction}

Although the ENSO cycle has a very obvious influence on life in and around the sea, its impact on marine, especially benthic, biota has not yet seen the attention it deserves. The very severe 1997-1998 El Niño was a key point in the research of impacts of the ENSO cycle on the biological environment. Information from before 1998 is rather scarce and scattered. Unfortunately, the 1997-1998 El Niño itself is also poorly documented, especially for sandy beaches. The work presented here was initiated with future El Niño events in mind. After all, it is very important to have data of longterm monitoring if one wants to observe anomalies caused by climate phenomena. For this paper, two eight-month periods are discussed. The first period coincides with the very strong and long lasting La Niña of 1999-2001, the second period can be considered normal.

Most of the studies on the impact of ENSO on marine benthos were done in subtidal areas and in subtropical or temperate regions. Only few papers concerning sandy beach fauna are available. The 1982-1983 and 1997-1998 "superEl Niños" seemed to have had a dramatic impact on the sandy beach fauna of Peruvian sandy beaches (Arntz, 1986; Arntz et al., 1987; Tarazona and Paredes, 1992; Arntz, personal comment), causing a decrease of up to $99.99 \%$ of the densities and a southward movement of $7^{\circ}$ latitude of some species, but with a positive effect on other species (Arntz, 1986). In contrast, Riascos (2002) could not find major changes in sandy beach macrobenthos densities on the Colombian coast during the 1997-1998 El Niño. Species richness dropped slightly during the end of 1997 but already recovered in January 1998, at a time SST anomalies were at their highest.

In contrast to the Peruvian system described by Tarazona and Paredes (1992), which is year-round dominated by the cold Humboldt Current, the Colombian beaches are part of an intrinsic warm-water system. Ecuador lies in between both, with warm water during the rainy season and relatively cold water during the rest of the year. Still, in general, the 


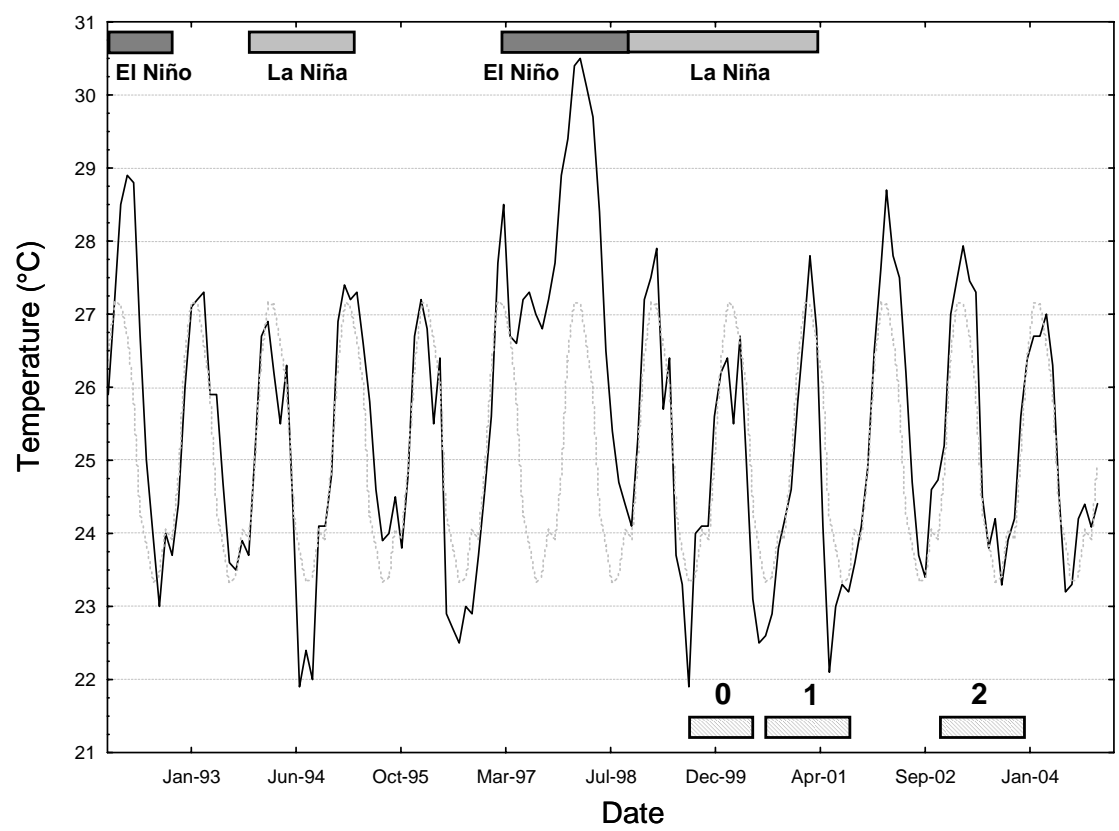

Fig. 1. SST values from the last 13 years for the EL Pelado station (full line: actual values; dotted line: long-term average). El Niño and La Niña events are marked at the top of the graph; the three phases are marked at the bottom of the graph.

Ecuadorian coast can be considered as a tropical environment. On top of that, Ecuador is, because of its position right on the equator, one of the countries in the tropical East Pacific that will be most severely struck by an El Niño or La Niña event.

In this paper we describe some results from the last $\mathrm{La}$ Niña period compared to a normal situation for Ecuador. We also give some speculations on how the Ecuadorian warm water system might react differently to ENSO events than the Peruvian cold water system.

\section{Material and methods}

From June 2000 through July 2001 and December 2002 through January 2004, the sandy beach of San Pedro de Manglaralto $\left(1^{\circ} 54^{\prime} 00^{\prime \prime} \mathrm{S}\right.$ and $\left.80^{\circ} 46^{\prime} 00^{\prime \prime} \mathrm{W}\right)$ was sampled on a bi-weekly basis, with a sampling technique as described by Aerts et al. (2004). Only the $1-\mathrm{mm}$ fraction was preserved and identified. Measured environmental variables were precipitation, cloudiness, surf water and air temperature, sediment characteristics, wave height and period and surf water salinity. The beach profile was assessed using a leveler. For this paper, only the months December-July of the two periods are discussed, named phase 1 and phase 2 , respectively. For beach characteristics, we refer to Aerts et al. (2004).

Additional data from 1999-2000 were used. The same beach was sampled once in August and November 1999 and February and June 2000, but only at low tide. These data are referred to as phase 0 .

Climatologic and oceanographic data were retrieved from the Oceanographic Centre of El Pelado (Fundación
CENAIM-ESPOL). This station is situated approximately $1 \mathrm{~km}$ offshore from the sampled beach.

Macrobenthos data were calculated to densities and expressed as ind $/ \mathrm{m}^{2}$. In this paper, only total densities and densities at higher taxonomic level (Polychaeta, Echinodermata, Crustacea, Bivalvia and Gastropoda) are discussed. Nonparametric Kruskal-Wallis and Mann-Whitney U and Spearman's rank correlation tests were performed using Statistica 6.0 (Statsoft, 1996).

\section{Results}

\subsection{Environment}

SST values from the last 13 years for EL Pelado are plotted in Fig. 1. The three phases are marked, as are the last ENSO events, based on both SST data and thermocline depth data for El Pelado. SST during sampling ranged from 21.9 to $27.9^{\circ} \mathrm{C}$, with an average of $25.6^{\circ} \mathrm{C}$. Average SST for the three phases was $23.8,25.1$ and $26.4^{\circ} \mathrm{C}$, respectively (KruskalWallis test: $\mathrm{p}<0.05$ ).

Correlation of the SST values for El Pelado with Niño3.4 anomalies showed an $\mathrm{r}$-value of $0.24(\mathrm{p}<0.05)$.

SST data for the seasons of the two phases are plotted in Fig. 2. The warm and wet season persisted from December through April, and the cold and dry season continued from May through November. Mean SST for the warm/wet season over the two phases was $26.8^{\circ} \mathrm{C}$, and $24.1^{\circ} \mathrm{C}$ for the cold/dry season (Mann-Whitney U test: $\mathrm{p}<0.05$ ). Mean SST for the warm/wet season for the first phase was $26.5^{\circ} \mathrm{C}$ and $27.1^{\circ} \mathrm{C}$ for the second phase (Mann-Whitney $U$ test: $\mathrm{p}<0.05$ ). For 

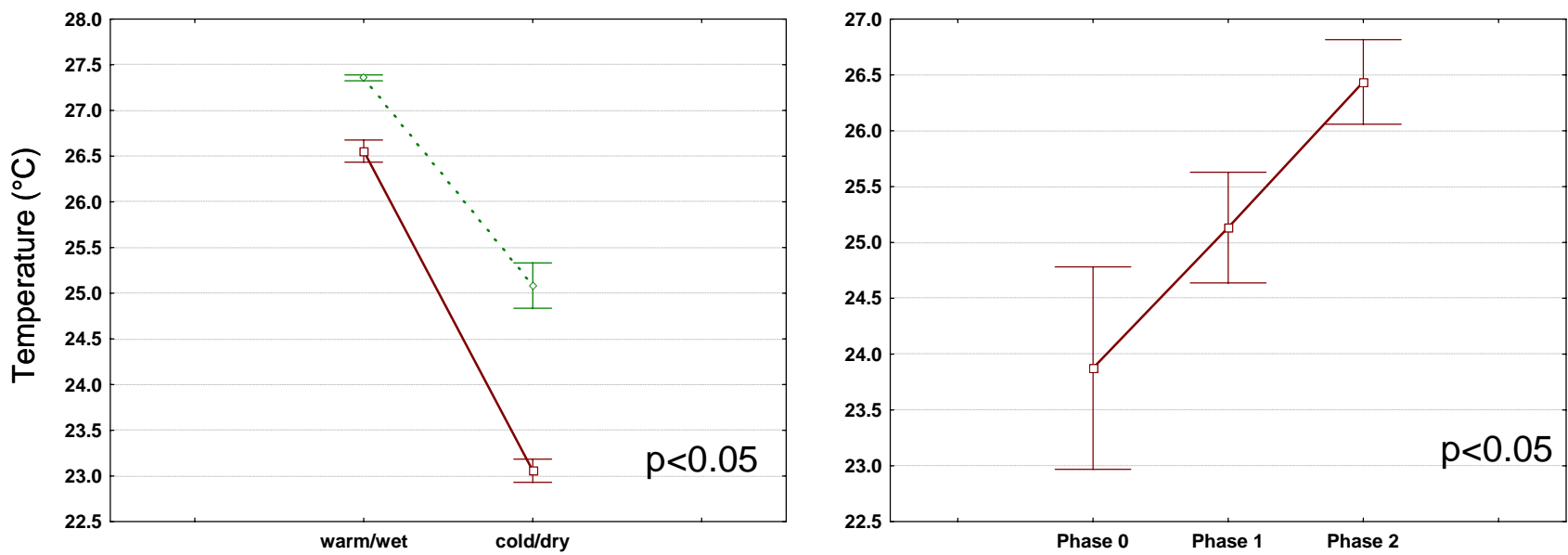

Fig. 2. Left: SST values from El Pelado for phase 1 (red line: La Niña) and phase 2 (green dotted line: Normal). Right: SST values from El Pelado for the three phases. Average values \pm SE.
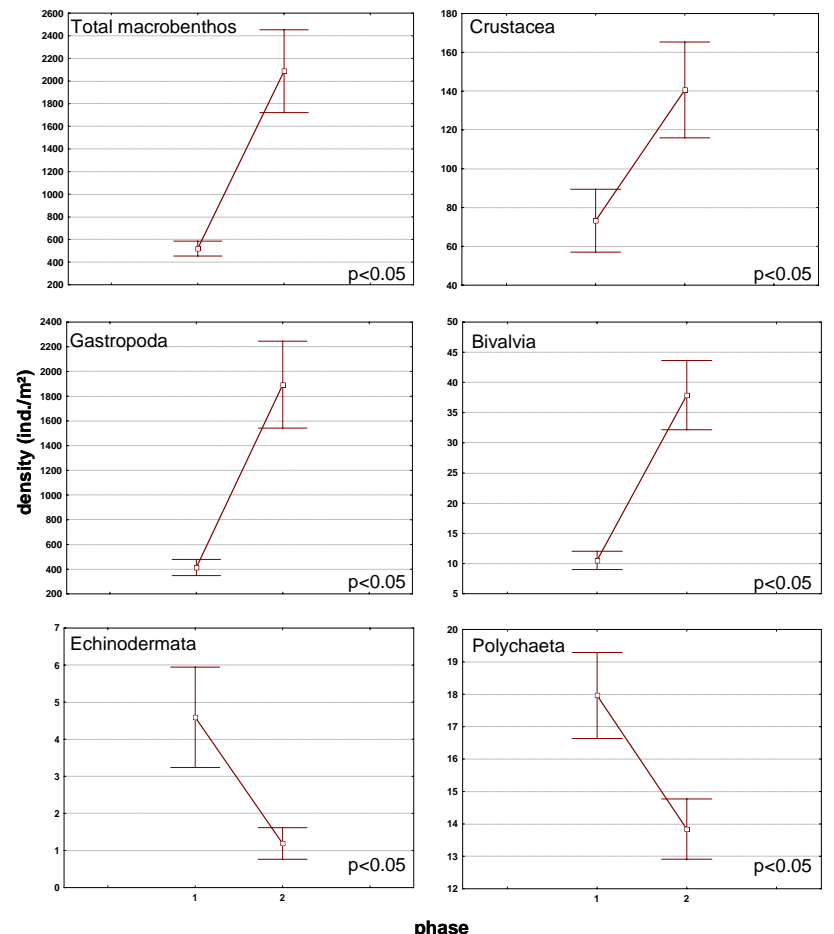

Fig. 3. Density values for total macrobenthos and higher taxonomic groups for phase 1 and 2 . Average values \pm SE.

the cold/dry season values were $23.1^{\circ} \mathrm{C}$ and $25.1^{\circ} \mathrm{C}$ respectively (Mann-Whitney $\mathrm{U}$ test: $\mathrm{p}<0.05$ ).

\subsection{Macrobenthos}

A total of 48 macrobenthic species were found during both periods, 13 of which in large numbers $\left(>2.5 \mathrm{ind} /{ }^{2}\right.$ averaged over all samples). Most dominant groups were crustaceans (17 species), bivalves (11 species), polychaetes (10 species), gastropods (7 species) and echinoderms (4 species).
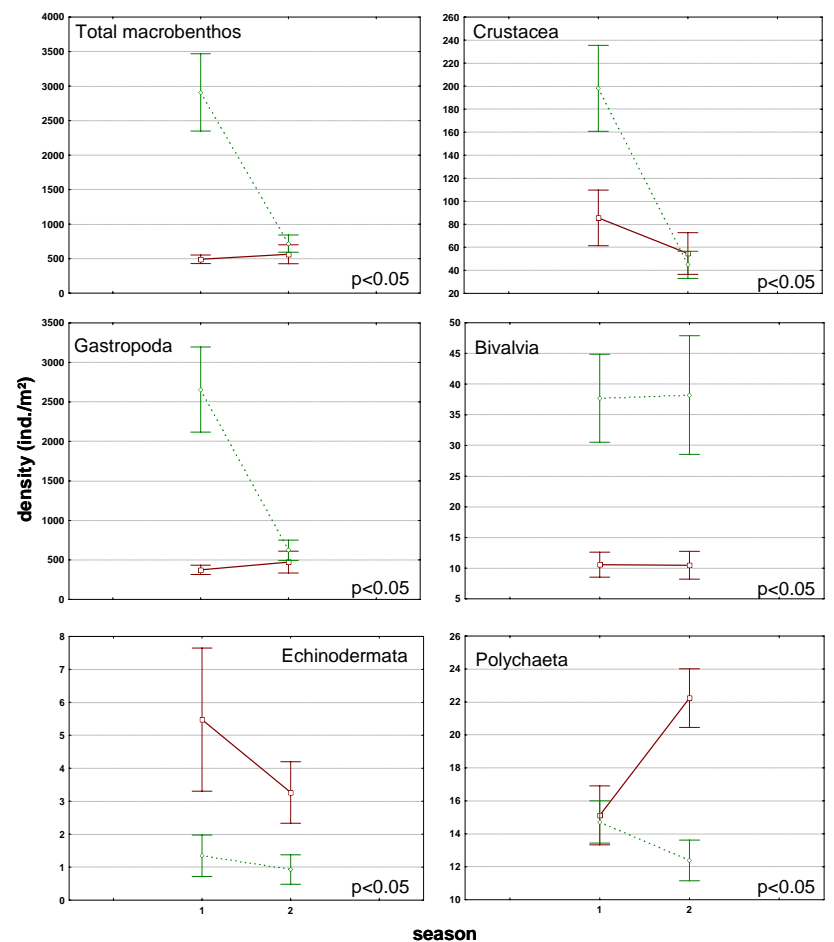

Fig. 4. Seasonal density values for total macrobenthos and higher taxonomic groups for phase 1 (red line: La Niña) and phase 2 (green dotted line: Normal). 1: warm/wet season; 2: cold/dry season. Average values \pm SE.

Comparison of the average densities for total macrobenthos and for the higher taxonomical groups between the two phases is shown in Fig. 3. From phase 1 to phase 2, average total densities increased with $300 \%$, mainly due to the increase in Mollusca $(+358 \%)$. Crustacea $(+92 \%)$ and $\mathrm{Bi}-$ valvia $(+260 \%)$ also increased significantly (Mann-Whitney U test: $\mathrm{p}<0.05$ ). Significant (Mann-Whitney $U$ test: $\mathrm{p}<0.05$ ) decreases were found for Polychaeta $(-23 \%)$ and Echinodermata $(-74 \%)$. 


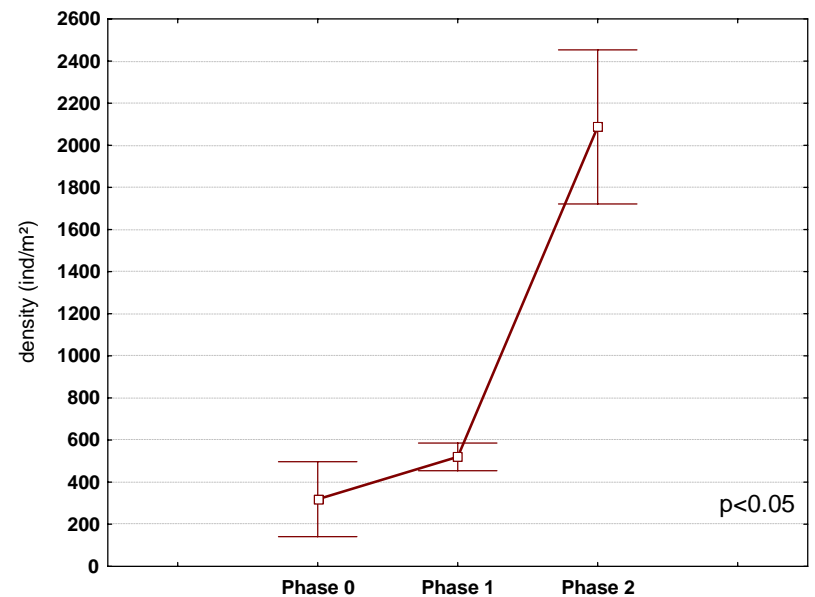

Fig. 5. Density values of the low water station for total macrobenthos and higher taxonomic groups for phase 0, 1 and 2. Average values \pm SE.

In Fig. 4 the differences in seasonality between the two phases are stated. It is easily seen that the differences mentioned before are mainly due to differences in the warm/wet season. Only for Polychaeta is the difference noticeable in the cold/dry season. For Bivalvia both seasons show equal differences.

\section{Discussion}

As for the entire east coast of South America, Ecuador was very severely struck by the 1997-1998 El Niño. This El Niño was followed by an almost as severe La Niña, which persisted until the end of 2001 for the Ecuadorian coast, and was only sporadically interrupted by normal periods. For the El Pelado station, this can especially be seen in the thermocline depth, which was very shallow during this whole $\mathrm{La}$ Niña period.

Although SST for the two phases are significantly different, especially for the warm/wet season, one could argue that this difference does not justify categorizing the first phase as a La Niña. However, if we look at the SST for the months preceding the first phase, we see markedly lower temperatures compared to the SST for the months preceding the second phase. This makes us confident that for the macrobenthos, the first phase can be regarded as a La Niña period, opposed to the normal second phase.

There was a very strong increase in macrobenthos densities from the first to the second phase, except for the Polychaeta and the Echinodermata, which make up a lesser part of the total sandy beach macrobenthos. Total macrobenthos densities during the peak of the La Niña (phase 0 ) were even lower than those from phase 1 (Fig. 5). From field observations and ongoing research, we know that the densities found during the second phase are comparable to current densities, suggesting they are to be considered as "normal". This leaves

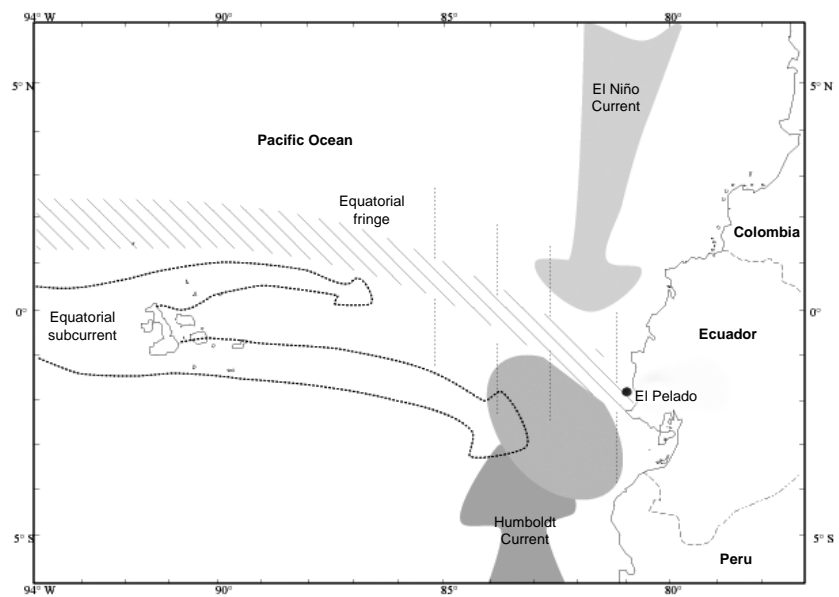

Fig. 6. Map of the central Ecuadorian coast with dominant currents.

us to explain the very low densities during the end of the $\mathrm{La}$ Niña phase.

The most obvious explanation would be to hold the very low densities during La Niña against the preceding "super-El Niño". Indeed, several papers describe a dramatic decrease in densities of certain sandy beach macrofauna during very strong El Niños (Arntz, 1986; Tarazona and Paredes, 1992), and it could be assumed that populations were still recovering during the first sampling period. However, these data were retrieved from studies in central and south Peru, where a strong influence of an El Niño on the cold water system is to be expected. Riascos (2002) could not find such a dramatic influence of the 1997-1998 El Niño on the sandy beach fauna of Colombia, a warm water system.

Unlike the Peruvian upwelling-system beaches (Arntz et al., 1987), the investigated beach is not a low species richness/high dominance system. With a total of 48 species over both campaigns, this Ecuadorian beach can be compared with many European beaches, considered to be highly diverse (Dexter, 1992; Degraer et al., 2003). With an average intertidal density of $1329 \mathrm{ind} / \mathrm{m}^{2}$ this beach could well prove to be a very productive beach, although no biomass data are available to check this statement. This difference between Ecuador and Peru might be related to the currents and upwelling off their coasts: Peru is year-round dominated by the cold Humboldt Current and has very strong upwelling of nutrient rich, cold water, whereas Ecuador has the interaction between the cold Humboldt and the warm El Niño Current (Fig. 6), leading to the typical seasonality in both temperature and upwelling. Thus, the Peruvian beaches are basically part of a cold water system; the Ecuadorian beaches are part of a warm water system. This can be verified by looking at the species composition. Indeed, Peru shares many species with Chile; Ecuador has many species that can be found in Panama and Colombia (Aerts et al., 2005; Dexter, 1974; Riascos, 2002; Jaramillo and Gonzales, 1991; Tarazona et al., 1986).

The alternative hypothesis we are proposing is that a $\mathrm{La}$ Niña, much more than an El Niño, will cause a dramatic 
effect on the sandy beach benthos of a warm water system such as is present in Ecuador. Unfortunately, we have little data to support this hypothesis from this study nor from other sandy beach benthos studies. We, therefore, suggest to carefully analyze all the existing data for benthic organisms from the warm water system and compare the influence of an El Niño and a La Niña. Furthermore, going into species level could prove very valuable for testing this hypothesis: does a La Niña typically cause the disappearance of warm water species while cold water species flourish, and vica versa?

Acknowledgements. The first author is financially supported by the FWO Flanders. We would like to thank all the people who contributed in the field and laboratory work for this study: N. Fockedey, J. Wittoeck, S. Guartatanga, L. Dominguez, V. Ruiz, D. Van Gansbeke and D. Schram and numerous students from ESPOL. Lab facilities and logistics in Ecuador were provided by ESPOL in Guayaquil in person of M. Pilar de Cornejo and by CENAIM in San Pedro by J. Calderon. Finally we would like to thank J. Chavarria for his help with the climatological data.

Edited by: P. Fabian and J. L. Santos

Reviewed by: W. Arntz and another referee

\section{References}

Aerts, K., Vanagt, T., Fockedey, N., et al.: Macrofaunal community structure and zonation of an Ecuadorian sandy beach (bay of Valdivia), Belg. J. Zool., 134 (1), 17-24, 2004.

Arntz, W.: The two faces of El Niño 1982-83, Meeresforschung, 1, 1-46, 1986.

Arntz, W., Brey, T., Tarazona, J., and Robles, A.: Changes in the structure of a shallow sandy-beach community in Peru during an El Niño event, in: The Benguela and Comparable Ecosystems, edited by: Payne, A., Gulland, J., and Brink, K., South African Journal of Marine Science, 5, 645-658, 1987.
Bocanegra, C., Carbajal, W., Oliva, J., and Ancieta, H.: Estructura de la comunidad de macroinvertebrados bentónicas en las playas arenosas de Trujillo. Anuario I Congreso Nacional de Biologia Pesquera (Trujillo, Perú), 213-218, 1985.

Degraer, S., Volckaert, S., and Vincx, M.: Macrobenthic zonation patterns along a morphodynamical continuum of macrotidal, low tide bar/rip and ultra-dissipative sandy beach, Est. Coast. Shelf Sc., 56, 459-468, 2002.

Dexter, D.: Sandy beach fauna of the Pacific and Atlantic coasts of Costa Rica and Colombia, Revista De Biologia Tropical, 22, 51-66, 1974.

Dexter, D.: Sandy beach community structure: the role of exposure and latitude, J. of Biog., 19, 59-66, 1992.

Jaramillo, E.: Sandy beach macroinfauna from the Chilean coast: zonation patterns and zoogeography, Vie et Milieu, 37, 165-174, 1987.

Jaramillo, E. and Gonzales, M.: Community structure of the macrofauna along a dissipative-reflective range of beach category in southern Chile, Studies on Neotropical Fauna and Environment, 26, 193-212, 1991.

StatSoft, Inc.: Statistica for WINDOWS, Computer program manual, Tulsa, OK, USA, 1996.

Riascos, J.: Changes in the macrobenthos of a sandy beach during, El Niño“ 1997-98 in the Malaga Bay, Colombian Pacific, Cienc. Mar., 28 (1), 13-25, 2002.

Tarazona, J., Paredes, C., and Igreda, M.: Estructura del macrobenthos en las playas arenosas de la zona de Lima, Perú, Revista Ciencias Universidad Nacional Mayor de San Marcos (Lima, Perú), 74, 103-116, 1986.

Tarazona, J. and Paredes, C.: Impacto de los eventos El Niño sobre las comunidades bentónicas de playa arenosa durante 19761986, in: Paleo ENSO Records, edited by: Ortlieb, L. and Marcharé, J., International Symposium, Lima, Perú, 299-303, 1992. 